\title{
TREATMENT WITH AUTOLOGOUS STEM CELL TRANSPLANTATION IN MULTIPLE MYELOMA PATIENTS - A 10-YEAR SINGLE CENTRE EXPERIENCE
}

Zlate Stojanoski, Borce Georgievski, Oliver Karanfilski, Sonja Genadieva-Stavrik, Aleksandra Pivkova, Lidija Cevreska University Clinic of Hematology, Medical faculty, Ss Cyril and Methodius University, Skopje, Republic of Macedonia

\author{
TERAPIJA BOLESNIKA SA MULTIPLIM MIJELOMOM AUTOLOGOM \\ TRANSPLANTIRACIJOM MATIČNIH ĆELIJA-DESETOGODIŠNJE \\ ISKUST VO JEDNOG MEDICINSKOG CENTRA \\ Zlate Stojanoski, Borče Georgievski, Oliver Karanfilski, Sonja Genadieva-Stavrik, Aleksandra Pivkova, Lidija Čevreska \\ Univerzitetska klinika za hematologiju, Medicinski fakultet, Univerzitet Ćirilo I Metodije, \\ Skoplje, Republika Makedonija
}

\section{ABSTRACT:}

Background - Multiple myeloma is a malignant neoplasm of plasma cells. Autologous stem cell transplantation (ASCT) has become the first line of therapy because of the low transplant-related mortality and its ability to prolong event-free survival, which results in improved quality of life. High-dose therapy (HDT) with ASCT should be part of the primary treatment in newly diagnosed patients under the age of 65 with adequate performance status and organ function.

Aim: The aim of this study is to present our ten-year experience in treating multiple myeloma patients with ASCT.

Materials and methods: Over a 10 -year period, we have performed 35 courses of HDT and consecutive ASCT in 31 patients with multiple myeloma (4 tandem transplantations). In this study, we retrospectively analysed the epidemiological characteristics of this group of patients.

Results: There were 14 female and 17 male patients. The median patient age was 52 years (range 43-64). The conditioning regimen used was high-dose Melphalan in doses of $200 \mathrm{mg} / \mathrm{m}^{2}$, and the dose used in the second (tandem) transplantation was $140 \mathrm{mg} / \mathrm{m}^{2}$. The median count of infused CD34+ cells was $3.65 \times 10^{6} / \mathrm{kg}$. As a source of added stem cells, we used phlebotomy in 3 patients. The median period from diagnosis to transplantations was 10 months. Of 31 patients, 21 (67\%) are currently alive and 10 (33\%) have died (3 renal failure, 3 multi-organ failure, 2 infections, and 2 fatal cerebral bleeding). The disease-free survival was 24 months.

Conclusions: ASCT offers better survival and quality of life compared to patients treated only with standard chemotherapy.

Keywords: multiple myeloma, stem cell transplantation

\section{SAŽETAK}

Multipli mijelom je maligna bolest plazma ćelija. Autologna transplantacija matičnih ćelija (ASCT) postala je prva linija terapije, uglavnom zbog niske smrtnosti i produženog preživljavanja, tako da dovodi do poboljšanja kvaliteta života. Terapija visokim dozama citostatika (HDT) sa ASCT treba da budu deo primarnog lečenja kod novootkrivenih pacijenata do 65 godina starosti uz adekvatan opšti klinički status.

Cilj: Cilj ovog rada je da predstavi deset godina našeg iskustva u lečenju obolelih od multiplog mijeloma putem ASCT.

Materijal i metode: Tokom desetogodišnjeg perioda, obavili smo 35 tretmana HDT i konsekutivnog ASCT kod 31 bolesnika sa multiplim mijelomom (4 Tandem transplantacije). U ovoj studiji smo analizirali retrospektivno epidemiološke karakteristike ove grupe pacijenata.

Rezultati: Odnos ženske i muške populacije iznosi 14:17, prosečne starosti: 52 godine (od 43-64). Visoke doze Melphalana u dozama $200 \mathrm{mg} / \mathrm{m} 2$ korišćene su kao kondicioni režim, u drugoj (tandem) transplantaciji $140 \mathrm{mg} / \mathrm{m} 2$. Srednji broj unetih CD34 + celija bio je 3,65 k106/kg. Kao izvor dodatih matičnih ćelija, koristili smo flebotomiju kod 3 bolesnika. Srednji period od dijagnoze do transplantacija bio je 10 meseci. Od 31 bolesnika, 21 (67\%) su živi, 10 (33\%) je umrlo (3 od bubrežne insuficijencije, 3 od multiorganske disfunkcije, 2 od infekcije, 2 od fatalnog cerebralnog krvavljenja. Preživljavanje bez ponovnih simptoa bolesti je 24 meseca.

Zaključci: ASCT obezbeđuje bolje rezultate za opstanak $i$ kvalitet života u poređenju sa pacijentima lečenim standardnom hemoterapijom.

Ključne reči: multipli mijelom, transplantacija matičnih ćelija

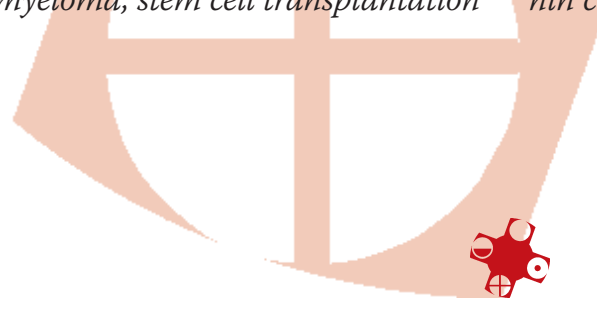

UDK: 616.15-006.44-089.84 ; 602.9 / Ser J Exp Clin Res 2013; 14 (1): 13-18 DOI: $10.5937 /$ SJECR14-1882 


\section{INTRODUCTION}

Multiple myeloma is a malignant haematological neoplasm of plasma cells that accumulate in bone marrow, leading to bone destruction and marrow failure (1). The disease develops in 1-4 per 100,000 people per year. The disease is more common in men and is twice as common in blacks as it is in whites (2). With conventional treatment (MP regimen), the prognosis is 3-4 years, and it may be extended to 5-7 years or longer with advanced treatments. Multiple myeloma is the second most common haematological malignancy $(13 \%)$ and constitutes $1 \%$ of all cancers. It was estimated that multiple myeloma would account for 19,920 new cancer cases in the United States in 2008. This figure includes 11,190 cases in men, 8,730 cases in women, and 10,690 deaths. The median age of myeloma patients at diagnosis is 69 years for men and 72 years for women (3). High-dose chemotherapy with autologous stem cells transplantation should be part of the primary treatment in newly diagnosed patients up to the age of 65 years with adequate performance status and organ function (Grade A; level Ib) according to the British Council of Haematology and UK Myeloma. The diagnostic criteria according to Durie and Salmon are used to confirm diagnosis (4). A bad prognosis is associated with partial or complete deletion of chromosome 13. Melphalan and prednisone (MP) have remained the standard therapy for decades, and the median survival with this therapy was approximately 3 years. High-dose therapy (HDT) and Autologous Stem Cell Transplantation (ASCT) havse been used in the management of myeloma since the efficacy of high dose melphalan in the treatment of high-risk myeloma and plasma cell leukaemia was first reported more than 20 years ago (5). ASCT has become the first line standard of care in patients deemed suitable for transplant. ASCT is the standard of care because of the low transplant-related mortality and the prolonged eventfree survival (EFS), which results in improved quality of life (6). Treatment with high-dose therapy and single autologous stem cell transplantation is a category I recommendation of the National Comprehensive Cancer Network. In young patients, the impact of dose intensity has been demonstrated, and single HDT supported with ASCT using a conditioning regimen with Melphalan alone should be considered as a standard of care (7). Double transplantation can be proposed to patients failing to achieve a very good partial response after the first stem cell transplantation (BCSH and UKMF Guidelines on the Management and Diagnosis of Multiple Myeloma Sept 2010). Stem cells are now almost exclusively derived from peripheral blood following stimulation with growth factors with or without chemotherapy. The optimal regimen for mobilising peripheral blood stem cells (PBSC) is unclear, but cyclophosphamide (1.5 to $\left.4 \mathrm{~g} / \mathrm{m}^{2}\right)$ with G-CSF is widely used. Purging harvested stem cells with monoclonal antibodies and/ or CD34+ stem cell selection does reduce contamination with tumour cells but does not influence the relapse risk (8). High-dose melphalan $\left(200 \mathrm{mg} / \mathrm{m}^{2}\right)$ remains the stan- dard conditioning prior to ASCT in first transplants, while a reduced dose of $140 \mathrm{mg} / \mathrm{m}^{2}$ is used in second transplantation. Recent studies have shown that the dose of melphalan can be increased to $220 \mathrm{mg} / \mathrm{m}^{2}$ (9), with improved PFS compared with historical controls, or to $240-300 \mathrm{mg} / \mathrm{m}^{2}$ in combination with amifostine. However, this approach is associated with increased toxicity (10). The addition of total body irradiation (TBI) results in increased toxicity with no improvement in response rate or PFS, whereas combination chemotherapy increases the toxicity $(11,12,13)$. Bortezomib has shown synergistic effects with melphalan without prolonged hematologic toxicity. The recently reported IFM phase 2 study enrolled 54 untreated patients to receive bortezomib $(1 \mathrm{mg} / \mathrm{m} 2 \mathrm{x} 4)$ and melphalan $(200 \mathrm{mg} /$ $\mathrm{m}^{2}$ ) as a conditioning regimen. They reported a response $\geq$ VGPR in $70 \%$ of patients and a $32 \% \mathrm{CR}$. There were no toxic deaths observed, and there was minimal peripheral neuropathy. Different studies have reported that the combination of chemotherapy plus new drugs can induce $70-90 \%$ partial response and $30-40 \%$ complete response $(14,15,16)$. The introduction of lenalidomide (analogue of thalidomide), bortezomib, and other novel agents have been extensively investigated to improve the duration of response $(17,18,19)$. According to guidelines from the British Haematology Council and International Myeloma Forum published in September 2010, the following recommendations are supported: HDT with ASCT should be part of the primary treatment in newly diagnosed patients up to the age of 65 years with adequate performance status and organ function (Grade A; level Ib); HDT with ASCT should be considered in patients aged $>65$ years with good performance status (Grade B; level IIa); and conditioning with melphalan alone, without TBI, is recommended (Grade B; level IIa). The usual dose is $200 \mathrm{mg} / \mathrm{m}^{2}$, but the dose should be reduced in older patients (over 65-70 years) and those with renal failure.

\section{MATERIALS AND METHODS}

Over the 10-year period from September 2000 to September 2010haematology, 195 stem cell transplantations were performed at our institution (University Clinic of Haematology, Medical Faculty, Skopje) on various haematological malignant and non-malignant diseases (AML: 109, ALL: 7, CML: 9, CLL: 1, NHL: 15, HD: 15, Myelofibrosis: 1, Ewing sarcoma: 1, Aplastic anaemia: 2, Multiple myeloma: 35 ). Allogeneic transplantation from HLA identical siblings were used to treat 56 patients, and autologous transplantation was used to treat 139 patients. Peripheral blood stem cells were used in 165 transplantations, and bone marrow was used in 30 transplantations. In 31 patients with multiple myeloma, we performed 35 high-dose chemotherapy and autologous stem cells transplantations (4 tandem transplantations) from peripheral blood stem cells. The high-dose conditioning regimen consisted of $200 \mathrm{mg} / \mathrm{m}^{2}$ Melphalan in first transplantation, while the second (tandem) transplantation used a dose 


\begin{tabular}{|c|c|c|c|c|c|c|c|c|c|}
\hline Patient & Age & Gender & Ig & $\begin{array}{c}\text { Bence- } \\
\text { Jones }\end{array}$ & $\begin{array}{c}\text { Renal } \\
\text { failure }\end{array}$ & Fracture & Ro.Th & $\begin{array}{l}\text { Months } \\
\text { Dg./Tx }\end{array}$ & $\begin{array}{c}\text { Months } \\
\text { A/D }\end{array}$ \\
\hline V.A & 64 & M & IgG & Negative & No & Th12/L1 & Yes & 6 & $\mathrm{~A}=92$ \\
\hline T.S. & 45 & $\mathrm{~F}$ & IgG & Negative & No & $\mathrm{No}$ & No & 4 & $A=96$ \\
\hline N.V.1 & 43 & M & IgG & Negative & No & Th12/L1 & Yes & 5 & $\mathrm{~A}=61$ \\
\hline V.Z.1 & 53 & $\mathrm{~F}$ & IgG & Negative & No & Hip & Yes & 11 & $A=58$ \\
\hline V.Z.2 & 53 & $F$ & IgG & Negative & No & No & Yes & 17 & $A=64$ \\
\hline G.Z.1 & 51 & $\mathrm{~F}$ & IgG & Negative & No & No & No & 7 & $A=63$ \\
\hline G.Z.2 & 51 & $F$ & IgG & Negative & No & No & No & 10 & $\mathrm{~A}=66$ \\
\hline S.J. & 46 & $\mathrm{~F}$ & IgG & Negative & No & No & No & 5 & $\mathrm{~A}=102$ \\
\hline A.Dz. & 50 & M & IgG & Negative & No & $\mathrm{L} 2$ & No & 22 & $\mathrm{~A}=75$ \\
\hline $\begin{array}{l}\text { N.V.2 } \\
\end{array}$ & 43 & $M$ & IgG & Negative & No & Th12/L1 & Yes & 8 & $A=69$ \\
\hline S.S. & 43 & $\mathrm{~F}$ & $\operatorname{IgA}$ & Positive & Yes & Negative & No & 12 & $\mathrm{~A}=6$ \\
\hline Z.G. & 50 & $M$ & IgA & Positive & Yes & L2L3 & Yes & 5 & $A=6$ \\
\hline A.L. & 43 & $M$ & IgG & Positive & Yes & No & No & 10 & $\mathrm{~A}=8$ \\
\hline M.T. & 50 & $M$ & IgG & Negative & No & Yes & Yes & 6 & $\mathrm{~A}=16$ \\
\hline M.Sh. & 52 & $\mathrm{M}$ & IgG & Negative & No & Yes & Yes & 8 & $\mathrm{~A}=12$ \\
\hline G.D. & 48 & $\mathrm{~F}$ & IgG & Negative & No & No & No & 5 & $\mathrm{~A}=15$ \\
\hline Kr.Kos. & 57 & $\mathrm{M}$ & IgG & Positive & No & No & No & 9 & $A=25$ \\
\hline Lj.M. & 56 & $M$ & IgG & Positive & Yes & $\mathrm{No}$ & No & 6 & $\mathrm{~A}=24$ \\
\hline M.D. & 48 & $M$ & IgG & Negative & No & No & No & 12 & $\mathrm{~A}=24$ \\
\hline Ка.К. & 52 & $\mathrm{~F}$ & $\operatorname{IgG}$ & Positive & Yes & No & No & 6 & $\mathrm{~A}=27$ \\
\hline S.B. & 48 & $\mathrm{~F}$ & IgG & Positive & Yes & Th9 & Yes & 20 & $\mathrm{~A}=32$ \\
\hline E.L. & 60 & $M$ & IgG & Negative & No & No & Yes & 11 & $\mathrm{~A}=34$ \\
\hline A.T. & 60 & $\mathrm{~F}$ & IgG & Negative & No & No & No & 6 & $\mathrm{~A}=6$ \\
\hline N.O.1 & 50 & $M$ & IgG & Negative & No & No & No & 4 & $A=36$ \\
\hline N.O. 2 & 50 & $M$ & IgG & Negative & No & No & No & 4 & $\mathrm{~A}=40$ \\
\hline M.M. & 47 & $\mathrm{M}$ & Kappa & Positive & Yes & No & No & 4 & $\mathrm{D}=50$ \\
\hline P.N. & 60 & $\mathrm{~F}$ & IgA & Negative & No & No & No & 12 & $\mathrm{D}=62$ \\
\hline A.C. & 57 & $\mathrm{~F}$ & IgG & Negative & No & No & No & 44 & $\mathrm{D}=127$ \\
\hline B.J. & 60 & $\mathrm{M}$ & $\operatorname{IgA}$ & Negative & No & L1 & Yes & 6 & $\mathrm{D}=66$ \\
\hline Z.S. & 59 & $\mathrm{M}$ & IgG & Negative & No & No & No & 12 & $\mathrm{D}=42$ \\
\hline Da.K & 63 & M & $\operatorname{IgG}$ & Negative & No & No & No & 20 & $\mathrm{D}=45$ \\
\hline Di.Ko & 46 & $M$ & IgG & Negative & No & No & No & 8 & $\mathrm{D}=36$ \\
\hline T.K. & 42 & $\mathrm{~F}$ & IgG & Negative & No & Th12 & Yes & 15 & $\mathrm{D}=44$ \\
\hline D.L. & 52 & $\mathrm{~F}$ & IgG & Positive & Yes & L2 & Yes & 22 & $\mathrm{D}=36$ \\
\hline A.L. & 56 & $\mathrm{~F}$ & $\operatorname{IgG}$ & Positive & Yes & Yes & No & 8 & $\mathrm{D}=54$ \\
\hline
\end{tabular}

Table 1. Patient epidemiological and clinical data

of $140 \mathrm{mg} / \mathrm{m}^{2}$ Melphalan. All patients were treated in a sterile room conditioned with HEPA filtration. In our study, we analysed 31 patients with multiple myeloma diagnosed according to Salmon and Durie diagnostic criteria. All patients were diagnosed and treated with induction therapy to reach remission at our hospital using various chemotherapeutic regimens. The standard chemotherapy regimen in our hospital is the VAD protocol in patients eligible for autologous transplantation. VAD (Vincristine, Adriamycin, Dexamethasone) is administered in 4 cycles every 28 days. Patients who achieved complete remission received priming therapy with Endoxan 2.0-4.0 g/ $\mathrm{m}^{2}$ plus G-CSF for peripheral stem cell mobilisation and harvesting. Non-responders received Thalidomide+Dexamethasone as a second line therapy for a 5-month period. As a third-line therapy, we used Bortezomib (Velcade). The median period from diagnosis to transplan- 
tation in our group of patients was 10 months (from 4-44 months). Usually, we performed 2 apheresis procedures (1-3) to harvest adequate numbers of CD $34+$ cells. A Baxter CS 3000 cell separator was used in 40 procedures, and a Cobe Spectra was used in 35 procedures. DMSO, Earhle's medium, and autologous plasma were used as a cryoprotectant. The cryopreservation was performed using a controlled Air Space Freezing system. The cryopreserved stem cells were stored at $-172^{\circ} \mathrm{C}$. The high-dose Melphalan was administered on day -2 and day -1 in 30-minute infusions through the central venous line. Approximately 24 hours after chemotherapy was completed, the autologous stem cells were thawed in a sterile bath and re-infused into the patient. As an anti-infective prophylaxis, every patient received Ciprofloxacin 1,0 gr/day, Difluconazol, or Itraconazole $200 \mathrm{mg} /$ day, i.v. Acyclovir 1500 $\mathrm{mg}$ /day., and i.v. immunoglobulins $0,1 / \mathrm{kg}$ once a week. GCSF was introduced from day +1 until neutrophil recovery. This research study was performed in accordance with the Declaration of Helsinki and was approved by the Local Ethics Committee. All patients signed a consent form.

\section{RESULTS}

Over a 10-year period at our hospital, we treated 31 patients with multiple myeloma. In 4 patients, we performed tandem transplantation (at a period from 4-6 months after the first transplantation). The dose of Melphalan was $200 \mathrm{mg} / \mathrm{m}^{2}$ in the first and $140 \mathrm{mg} / \mathrm{m}^{2}$ in the second trans- plantation. The median count of re-infused CD34+ cells was $3,65 \times 10^{6} / \mathrm{kg}$ b.w. (from $2,0-12,5$ ). Engraftment was established on day +11 (from day +7 to day +16 ). The median number of days for G-CSF use was 10 days (from 7-14 days). During the first 30 days after transplantation, which is the period of aplasia, there were only a few infective complications in our group of patients. The early transplant related mortality (until day +100 ) was 0 . The most common complication after transplantation was mucositis. There was Grade IV mucositis present in 8 patients. There were central venous catheter infections with coagulase negative staphylococcus in 5 patients. The fatal outcomes were due to renal failure in 3 patients $(50,62$, and 127 months after transplantation), multi-organ failure in 3 patients $(66,42$, and 45 months after transplantation), infections in 2 patients (one with aggressive hepatitis B virus infection 36 months after transplantation, and one with pneumonia 44 months after transplantation), and 2 fatal cerebral bleeding (36, 54 months after transplantation). All of the patients died with active relapse of myeloma disease.

\section{DISCUSSION}

Multiple myeloma was the most frequent indication for which autologous stem cell transplantation is performed (20). However, autologous stem cell transplantation is not curative, and most patients relapse within a median of 3 years. The median survival after transplantation in our

\begin{tabular}{|l|l|}
\hline Number of patients & 31 \\
\hline Number of transplantations & 35 (4 tandem transplantations) \\
\hline Age & 52 years (43-64) \\
\hline Gender & Male: $17(55 \%)$ Female: $14(45 \%)$ \\
\hline Myeloma types & IgG =30(85\%); IgA=4(11\%) Light chain=1(4\%) \\
\hline Bence-Jones proteinuria & $10(28 \%)$ \\
\hline Lytic bone lesion with fracture & $13(37 \%)$ \\
\hline Previous radiotherapy & $13(37 \%)$ \\
\hline Period from Diagnosis to transplantation & $10(4-44$ months $)$ \\
\hline Living 21 patients $(67 \%)$ & $6-102$ months after transplantation \\
\hline Deceased 10 patients $(33 \%)$ & $36-127$ months after transplantation \\
\hline
\end{tabular}

Table 2. Summary of patient characteristics treated with autologous transplantation

\begin{tabular}{|l|l|l|}
\hline & Median & Range \\
\hline number of apheresis & 2 & $1-3$ \\
\hline counts of infused CD34+ cells & 3,65 & $2,0-12,5$ \\
\hline days of G-CSF & 10 & $7-14$ \\
\hline day of engraftment & +11 & $+7-+16$ \\
\hline blood transfusions & 2 & $0-6$ \\
\hline platelet transfusions & 6 & $0-18$ \\
\hline
\end{tabular}

\begin{tabular}{|l|l|}
\hline Febrile episodes & 10 \\
\hline Central venous catheter infections & 5 \\
\hline Mucositis & 8 \\
\hline Pneumonia & 2 \\
\hline Neutropenic enterocolitis & 2 \\
\hline
\end{tabular}

Table 3. Graft characteristics

Table 4. Early post-transplant complications 
group was 38 months (from 36 months to 127 months after transplantation). The superiority of autologous stem cell transplantation over conventional chemotherapy was first demonstrated by The Intergroupe Francophone du Myelome (IFM) (21). In multiple myeloma, the standard high-dose therapy is single agent Melphalan at a dosage of $200 \mathrm{mg} / \mathrm{m}^{2}$. Attempts to improve this regimen with conventional drugs or total body irradiation have failed to improve the response rate but have increased both haematologic and non-haematologic toxicities. A synergistic effect between bortezomib and melphalan has been demonstrated. Allogeneic stem cell transplantation was introduced in the treatment of multiple myeloma 25 years ago, but the toxicity was very high, with a transplant related mortality in excess of $50 \%$ in studies including heavily pre-treated patients $(22,23,24,25)$. Allogeneic SCT using conventional conditioning and HLA-matched sibling donors can result in long-term survival and may have a role in younger patients, but it is an option for only a very few selected patients. One of the main problems with allografting using conventional conditioning was the high transplant-related mortality (TRM). However, there is now evidence from both the EBMT and individual centre studies that this has improved in the last 10 years. The 2 -year TRM has fallen from $46 \%$ before 1994 to $30 \%$ since 2000 (Russell et al, 2000; Gahrton et al, 2001). This may reflect transplantation earlier in the course of the disease, improved supportive care and/or careful patient selection. Several well-designed, non-randomised studies show little benefit from allografts in the progressive disease/relapse situation (Einsele et al, 2003; Kröger et al, 2004). Patients transplanted in first remission have a $60 \%$ chance of entering $C R$, and one-third of these patients are in a persistent molecular remission with a very low risk of relapse (Corradini et al, 2003). Therefore, allografts should be performed in first chemo-sensitive phase. The potential benefit of this outcome may justify the risks of allogeneic SCT in patients up to 50 years of age, particularly for patients early in their disease. Therefore, allogeneic stem cell transplantation should not be proposed to patients older than 50 years of age. The combination of high-dose chemotherapy and autologous stem cell transplantation is an effective strategy to treat multiple myeloma patients and appears superior to standard chemotherapy. Novel agents, such as lenalidomide, bortezomib, and other treatments, have improved the survival of these patients. Introducing these agents earlier in the course of the disease together with autologous stem cell transplantation will improve the duration of remission.

\section{REFERENCES}

1. Attal M, Harousseau JL, Stoppa AM, et al. A prospective randomized trial of autologous bone marrow transplantation and chemotherapy in multiple myeloma. Intergroupe Francais du Myelome. N Engl J Med. 1996;335:1844-1845.
2. Child JA, Morgan GJ, Davies FC, et al. High-dose chemotherapy with hematopoietic stem-cell rescue for multiple myeloma. N Engl J Med. 2003;348:1875-1883.

3. Palumbo A, Bringhen S, Petrucci MT, et al. Intermediate-dose melphalan improves survival of myeloma patients aged 50 to 70: results of a randomized controlled trial. Blood. 2004;104:3052-3057.

4. Fermand JP, Katsahian S, Divine M, et al. High-dose therapy and autologous blood stem-cell transplantation compared with conventional treatment in myeloma patients aged 55 to 65 years: long-term results of a randomized control trial from the Group MyelomeAutogreffe. J Clin Oncol. 2005;23:9227-9233.

5. Blade J, Rosinol L, Sureda A, et al. High-dose therapy intensification compared with continued standard chemotherapy in multiple myeloma patients responding to the initial chemotherapy: long-term results from a prospective randomized trial from the Spanish cooperative group PETHEMA. Blood. 2005;106:3755-3759.

6. Barlogie B, Kyle RA, Anderson KC, et al. Standard chemotherapy compared with high-dose chemoradiotherapy for multiple myeloma: final results of the phase III US Intergroup trial S4321. J Clin Oncol. 2006;24:929-936.

7. Moreau P, Facon T, Attal M, et al. Comparison of $200 \mathrm{mg} / \mathrm{m}^{2}$ melphalan and 8Gy total body irradiation plus $140 \mathrm{mg} / \mathrm{m}^{2}$ melphalan as conditioning regimens for peripheral blood stem cell transplantation in patients with newly diagnosed multiple myeloma. Final analysis of the IFM95-02 randomized trial. Blood 2002;99:731-735

8. Barlogie B, Jagannath S, Desikan KR, et al. Total therapy with tandem transplant for newly diagnosed multiple myeloma. Blood. 1999;93:55-65.

9. Attal M, Harousseau JL, Facon T, et al. Single versus double autologous stem cell transplantation for multiple myeloma. N Engl J Med. 2003;349:2495-2502.

10. Cavo M, Zamagni E, Cellini C, et al. Single versus tandem autologous transplants in multiple myeloma: Italian experience. J Clin Oncol 2007;25:2434-2441.

11. Fermand JP. Single versus double high-dose therapy supported with autologous blood stem cell transplantation using unselected or CD34 enriched ABSC: results of a two by two designed randomized trial in 230 young patients with multiple myeloma [abstract]. Hematol J. 2005;90:40.

12. Sonneveld P, Van Der Holt B, Sergeren CM, et al. Intensive versus double intensive therapy in untreated multiple myeloma. Updated analysis of the prospective phase III study Hovon 24-MM [abstract]. Hematol J. 2005;90:37-38.

13. Goldschmidt H. Single versus double high-dose therapy in multiple myeloma: second analysis of the trial GMMG-HD2 [abstract]. Hematol J. 2005;90:38.

14. Greipp PR, San Miguel JS, Durie BG, et al. International staging system for multiple myeloma. J Clin Oncol. 2005;23:3412-3420 
15. Avet-Loiseau H, Attal M, Moreau P, et al. Genetic abnormalities and survival in multiple myeloma: the experience of the Intergroupe Francophone du Myélome. Blood. 2007;109:3489-3495.

16. Shaughnessy JD, Zhan F, Burrington BE, et al. A validated gene expression model of high-risk multiple myeloma is defined by deregulated expression of genes mapping to chromosome 1. Blood. 2007;109:2276-2284.

17. Cavo M, Zamagni E, Tosi P, etal. Superiority of thalidomide and dexamethasone over vincristine-doxorubicin-dexamethasone as primary therapy in preparation for autologous transplantation for myeloma. Blood. 2005;106:35-39.

18. Macro M, Divine M, Uzunhan Y, et al. Dexamethasone plus Thalidomide compared to VAD as a pre-transplant treatment in newly diagnosed multiple myeloma [abstract]. Blood. 2006;108:Abstract no. 57.

19. Rajkumar SV, Blood E, Vesole D, et al. Phase III trial of thalidomide plus dexamethasone compared with dexamethasone alone in newly diagnosed multiple myeloma. J Clin Oncol. 2006;24:431-436.

20. Goldschmidt H, Sonneveld P, Breitkreuz I, et al. Phase III study on the effect of thalidomide combined with highdose melphalan in myeloma patients up to the age of 65 years [abstract]. Blood. 2005;106:Abstract no. 424.s

21. Harousseau JL, Attal M, Leleu X, et al. Bortezomib plus dexamethasone as induction treatment prior to autologous stem cell transplantation in patients with newly diagnosed multiple myeloma. Haematologica. 2006;91:1498-1505.
22. Crawley C, Iacobelli S, Björkstrand B, et al. Reducedintensity conditioning for myeloma: lower nonrelapse mortality but higher relapse rates compared with myeloablative conditioning. Blood. 2007;109:3588-3594.

23. Badros A, Barlogie B, Siegel E, et al. Improved outcome of allogeneic transplantation in high-risk multiple myeloma patients after non-myeloablative conditioning. J Clin Oncol. 2002;20:1295-1303.

24. Kroger N, Schwerdtfeger R, Kiehl M, et al. Autologous stem cell transplantation followed by a dose-reduced allograft induces high complete remission rate in multiple myeloma. Blood. 2002;100:755-760.

25. Maloney D, Molina A, Sahebi F, et al. Allografting with nonmyeloablative conditioning following cytoreductive autografts for the treatment of patients with multiple myeloma. Blood. 2003;101:3447-3454.

26. Garban F, Attal M, Michallet M, et al. Prospective comparison of autologous stem cell transplantation followed by dose-reduced allograft (IFM 99-03 trial) with tandem autologous stem cell transplantation (IFM 9904 trial) in high-risk de novo multiple myeloma. Blood. 2006;107:3474-3480.

27. Bruno B, Rotta M, Patriarca F, et al. A comparison of allografting with autografting for newly diagnosed myeloma. N Engl J Med. 2007;356:1110-1120.

28. 4. B G M Durie, J-L Harousseau, J S Miguel, at all. International uniform response criteria for multiple myeloma Leukemia (2006) 20, 1467-1473. doi: 10.1038/ sj.leu.2404284 